\title{
Membrane-Assisted Enzymatic Production of Galactosyl-Oligosaccharides from Lactose in a Continuous Process
}

\author{
P. Czermak*, M. Ebrahimi, K. Grau, S. Netz \\ University of Applied Sciences Giessen-Friedberg, Department of \\ Biotechnology, Wiesenstr. 14, 35390 Giessen, Germany \\ G. Sawatzki \\ SciNuTec GmbH, Ricarda Huch Str. 13, 35516 Münzenberg, Germany \\ P. H. Pfromm* \\ Department of Chemical Engineering, Kansas State University \\ Manhattan, Kansas, 66506, U.S.A., pfromm@ @su.edu, 785-532-4312, fax 785-532-7372 \\ Published in the Journal of Membrane Science, volume 232(1-2), page 85 (2004)
}

\begin{abstract}
Functional foods such as oligosaccharides have attained significant acceptance in Japan and are attracting interest elsewhere. Beneficial physiological properties are attributed to oligosaccharides. Here, we describe the continuous production of oligosaccharides from a low-cost substrate (lactose) in a continuous membrane-assisted reactor (both polymeric and inorganic membranes were tested). Different enzymes, a number of feed concentrations, and different average residence times were investigated. The enzymes were used in their native form. Retention and recycling of the enzyme was successful, while the products together with some unreacted substrate and byproducts were removed as the ultrafiltration permeate. For the ultrafiltration, a steady-state flux of about $201 / \mathrm{m}^{2} \mathrm{hr}$ was achieved. A maximum oligosaccharide concentration of over $40 \% \mathrm{w} / \mathrm{w}$ was reached with an average residence time of $1 \mathrm{hr}$ and a feed lactose concentration of $31 \% \mathrm{w} / \mathrm{w}$. Pilot scale experiments based on the laboratory tests are also reported.
\end{abstract}

Keywords: ultrafiltration, oligosaccharides, enzymatic catalysis, lactose

* to whom correspondence shall be addressed 


\section{Introduction}

Functional foods have recently attracted much attention ([1]-[5], for an overview see [1]). An interesting class of compounds in this respect are the galactosyl-oligosaccharides. Galactosyloligosaccharides consist of a galactosyl-galactose chain with a terminating glucose (Figure 1). These compounds are non-digestible carbohydrates, and are also termed soluble dietary fiber. Many positive physiological effects in humans are ascribed to galactosyl-oligosaccharides, from selective improvement of growth of beneficial intestinal bacteria to improved absorption of calcium and magnesium, and improved detoxification of the body [2-5]. Some galactosyl-oligosaccharides are found in human breast milk [6].

Galactosyl-oligosaccharides can be derived from lactose by enzymatic catalysis using $\beta$ galactosidases (Figure 2). The kinetics of the reactions summarized elsewhere [7] and reflected in Figure 2 are not trivial. Overall, it can be said that lowering the water content is beneficial to obtain oligosaccharides. In addition, long reaction times have been shown in batch experiments to result in hydrolysis of the oligosaccharides yielding mainly simple sugars [7]. A number of steps could be taken if oligosaccharide yield is to be maximized: use of highly concentrated starting substrate (lactose), lowering of the thermodynamic activity of water (for example using a micro-aqueous environment), modification of the enzyme, and removal of the desired product (oligosaccharides) from the reaction mixture. In the work reported here, the product was continuously removed (along with water, some substrate and simple sugar byproducts) from a stirred tank reactor using crossflow membrane ultrafiltration, while the enzyme was retained by the membrane and returned to the reactor (Figure 3). This concept has been developed and investigated in detail for other enzymatically catalyzed reactions [11] and has been applied to lactose hydrolysis [8, 10]. This 
configuration also allows variation of the residence time for optimization of the yield and composition of the oligosaccharide fraction. In addition, the feed concentration of the substrate lactose was tested up to high levels. The issues of product inhibition, contamination in multi-step processes, and the continuous use of enzyme without the need for deactivation highlight the advantages of the continuous process investigated here.

Some information on the use of immobilized enzymes for this synthesis can be found in the literature $[7,8]$. It appears, however, that mass transfer limitations are an issue when immobilized enzymes are used [12]. With immobilized enzymes a significant portion of the oligosaccharides appears to be enzymatically hydrolyzed before reaching the bulk solution from where the valuable product could be recovered. Ultrafiltration allows the option to use immobilized or not immobilized (native) enzymes.

In summary, the work reported here addresses the issues of product hydrolysis and inhibition of the reaction by galactose in enzymatic oligosaccharide production from lactose by continuous removal of the product from the enzymatic reactor via ultrafiltration. Native enzymes were used since the ultrafiltration step returns the enzyme to the reactor (Figure 3). The process is run continuously.

\section{Experimental}

\section{Enzymes}

Sources, properties, and experimental conditions for the commercial ß-galactosidases used in this work are given in Table 1. B-galactosidase has a molecular weight exceeding 100,000 g/mol [9]. This is clearly above the nominal molecular weight cutoff (MWCO) of the most "open" membrane used here $(50,000 \mathrm{~g} / \mathrm{mol})$. 
The choice of enzymes used here encompasses essentially all commercially available enzymes that would be candidates for transfer of this work to the industrial scale.

\section{Membranes}

Table 2 lists the membranes used here. The nominal molecular weight cutoff (MWCO) ranges to $50,000 \mathrm{~g} / \mathrm{mol}$, which indicates that the enzymes used here $(>100,000 \mathrm{~g} / \mathrm{mol})$ should be retained by the membranes. The polymeric membrane (UF-PES-050H, Amafilter GmbH, Düsseldorf, Germany) was used in form of a flat sheet in a filter holder (active membrane area 64

$\mathrm{cm}^{2}$ ). The flow was directed in a spiral pattern using channels (height about $1 \mathrm{~mm}$ ) in the top of the filter holder.

The ceramic membrane (atech innovations $\mathrm{GmbH}$, Gladbeck, Germany) was a cylindrical monolith (diameter $25.4 \mathrm{~mm}$ ) with 19 flow channels for the feed (selective layer $\mathrm{TiO}_{2}$ on $\mathrm{ZrO}_{2}$, porous $\mathrm{Al}_{2} \mathrm{O}_{3}$ structural support, flow channel diameter $3 \mathrm{~mm}$, total active filtration area of the monolith $0.1 \mathrm{~m}^{2}$ ). The monolith was contained in a stainless steel housing.

The membranes were rinsed after every experiment with copious amounts of the aqueous buffer solution (see below).

\section{Membrane-assisted continuous reactor}

A fed-batch stirred tank reactor (max. volume 2 1) was used with a membrane module as shown in Figure 3. The enzyme is retained in the reactor while a solution containing the relatively low molecular weight products (oligosaccharides) some of the substrate (lactose) and some byproduct (glucose, galactose) passes through the membrane. Based on the large difference between the nominal molecular weight cutoff of the membranes and the molecular weight of the materials involved it is reasonable to assume that the retentate composition is identical to the 
permeate composition, except for the presence of enzyme in the retentate. No leakage of enzymes was observed as determined by the enzyme activity in the permeate. The pressure readings of P1 and P2 (Figure 3) were always approximately equal. This pressure is reported as the transmembrane pressure. No permeate was recycled. Different average residence times were achieved by keeping the permeate flux (at $201 / \mathrm{m}^{2} \mathrm{hr}$, see also Figure 4) and feed flow rate constant and equal while using different reactor volumes. Reported experimental results where oligosaccharides were produced are for steady-state conditions.

\section{Chemicals}

Deionized water was used. Potassium phosphate $(5 \mathrm{mmol} / \mathrm{l})$ was used as a buffer in all experiments. The a-lactose was food grade (99.95\% pure, Meggle GmbH, Wasserburg, Germany).

\section{Analytical}

High performance anion exchange chromatography and pulsed amperometric detection (HPAEC-PAD ) using a Dionex system (Dionex Corporation, Sunnyvale, CA) was used to analyze the composition of products from the reactor. Additionally we used thin film chromatography and enzymatic assays.

\section{Results and Discussion}

\section{Fluxes of polymeric and ceramic membranes with model solutions}

The fluxes of the organic and inorganic membranes with pure buffer solution compared to a lactose solution (including enzyme) are shown in Figure 4. As expected, the more "open" polymeric membrane allows a significantly higher flux for the buffer at comparable transmembrane pressure. It is also clear that the lactose- and enzyme-containing solutions for both membranes were in a regime where the membrane flux was independent of trans-membrane 
pressure (likely due to concentration polarization). The fluxes obtained for conditions used for actual catalysis runs are nearly identical regardless of the differences in feed solution composition.

In Figure 4 the Reynolds numbers for the ceramic membrane (with lactose/enzyme containing feed) were about 510, 660, and 720 at 1,2 , and 2.5 bar trans-membrane pressure, respectively as determined from the channel geometry and volumetric flow rates..

Oligosaccharide concentration using polymeric or ceramic membranes and different enzymes and average residence times

The product concentration of oligosaccharides was determined at different average residence times defined as

$$
\mathrm{t}=\mathrm{V}_{\mathrm{r}} / \mathrm{V}
$$

where $t$ is the average residence time in hours, $V_{r}$ is the reaction volume in $\mathrm{m}^{3}$, and $\mathrm{v}$ is the permeate flowrate (equal to the feed flowrate) in $\mathrm{m}^{3} / \mathrm{hr}$. The residence time was changed by varying the reaction volume while keeping the feed and permeate flow rates equal and constant.

Figure 5 shows oligosaccharide product concentrations with the ceramic or the polymeric membranes at 60 minutes residence time and comparable lactose feed concentrations. The oligosaccharide concentration rises with rising feed lactose concentration as expected. The better performance of Maxilact L 2000 (optimum near neutral pH) is also expected due to the properties of the enzyme [7].

Our results compare favorably as far as the product oligosaccharide yield with those of Lopez Leiva and Guzman where whey with relatively low lactose concentration was used as the substrate [10]. High substrate lactose concentration is essential for process economy. The results reviewed by Mahoney [7] are confirmed in our continuous membrane-assisted reactor. 
Figure 6 shows that at longer average residence times (exceeding about one hour) the product concentration (oligosaccharide) levels off or decreases due to enzymatically catalyzed hydrolysis of the product back to mono- and disaccharides. An increase in mono- and disaccharides concurrent with oligosaccharide decrease has been observed (see below). It is expected that at very long average residence times the overwhelming majority of the sugars will be converted to monosaccharides [7]. The resulting high galactose concentrations also inhibit formation of our desired product. These long residence times (on the order of several hours) were not reached here.

In summary, significant product (oligosaccharide) concentrations can be achieved in the permeate. The maximum oligosaccharide concentrations depend on the enzyme preparation and the concentration of the substrate in the feed. The average residence time should be kept reasonably short due to increased hydrolysis of the desired product. A potential avenue to improve the process may be separation of unreacted lactose from the permeate and recycling to the reactor.

\section{Composition of products from enzymatic production of galactosyl-oligosaccharides}

Figure 7 shows an HPAEC-PAD-chromatogram of saccharides produced in one of our continuous experiments. This chromatogram clearly shows the success of the enzymatically catalyzed production of oligosaccharides. Figure 8 shows for comparison an HPAEC-PAD chromatogram of product from our experiments by an external source (Institut für Technologie der Kohlenhydrate, Braunschweig, Germany). Plant-derived standards are included in this chromatogram as well as a concentrated commercial galactosyl-oligosaccharide product (BorculoDomo Ingredients - Vivinal GOS).

The comparison of Figure 7 and 8 verifies the usefulness of our chromatography to quantify the amount of galactosyl-oligosaccharides in our experiments. 


\section{Pilot scale trials}

Pilot trials were recently performed using a ceramic membrane (Membralox monolith, 19 channels with $6 \mathrm{~mm}$ diameter, Pall Exekia, Bazet, France) with a nominal cut off of 50,000 g/mol (average pore diameter of 50 nanometer according to the manufacturer) and an active membrane area of $0.36 \mathrm{~m}^{2}$ (1.2 - 2.4 bar trans-membrane pressure, average cross-flow velocity $\left.5 \mathrm{~m} / \mathrm{s}\right)$. The enzyme was Maxilact LX $5000\left(\mathrm{pH} 7.5,40^{\circ} \mathrm{C}\right)$ and the feed lactose concentration was $20 \% \mathrm{w} / \mathrm{w}$ in a $0.5 \mathrm{mmol} / \mathrm{l}$ phosphate buffer. A feed concentration of $20 \%$ lactose was used since this is typical of whey concentrated by nanofiltration which is a possible substrate. The average residence time was about $30 \mathrm{~min}$. The membrane permeate flux declined from initially $140 \mathrm{l} / \mathrm{m}^{2} \mathrm{hr}$ to $70 \mathrm{l} / \mathrm{m}^{2} \mathrm{hr}$ after one hour of run time and then leveled out at $701 / \mathrm{m}^{2} \mathrm{hr}$ for the remaining time (total run time 2.5 hrs) but the pure water flux measured before this run was recovered after cleaning with $\mathrm{NaOH}$ and Ultrasil. The oligosaccharide concentration ranged from 19-20\%w/w in the ultrafiltration permeate. The run yielded about 2,900 grams of oligosaccharides. Tests of enzyme activity, however, showed some loss of enzyme through the membrane. This was not expected considering the nominal cutoff of the membrane, compared to our laboratory results. We suspect that the nominal cut off may not fully represent the membrane properties under the conditions used here. Overall, this initial pilot test is quite encouraging.

\section{Concluding Remarks}

Our results show that a membrane-assisted continuous reactor can perform well in the production of oligosaccharides from lactose. The enzyme is retained essentially completely in the laboratory tests while the product is removed from the reactor together with some substrate and byproducts. Membrane flux (about $20-301 / \mathrm{m}^{2} \mathrm{hr}$ at 1.5 bar trans-membrane pressure) is limited by 
concentration polarization but stable. Short average residence times (less than 1 hour) lead to the highest yield of oligosaccharides. Initial pilot tests indicate that this process can be successful if the membrane characteristics are appropriate to retain the enzyme. Work is under way to use simulated moving bed chromatography to address the issue of recycling of unreacted materials from the ultrafiltration permeate to the reactor.

\section{Acknowledgements}

The authors are grateful for financial support by the Technologie Stiftung Hessen TSH, Wiesbaden, Germany, and SciNuTec GmbH, Münzenberg, Germany through the model project "Biocera". Meggle GmbH, Gist-Brocades, Gamma Chemie and Amano are gratefully acknowledged for the donation of lactose and enzyme preparations, respectively. The authors also thank Dr. Florence Lutin (Eurodia, Wissous, France) and Dr. Simona Pajardi (Hydro Air Research, Merlino, Italy) for the opportunity to carry out the pilot scale experiments and for their assistance with the experiments. The authors also thank Dr. Wullbrandt from the Institut für Technologie der Kohlenhydrate, Braunschweig, Germany, for the assistance in HPAEC analytics of the galactosyloligosaccharides. 


\section{Figure Captions}

Figure 1: General chemical structure of galactosyl-oligosaccharides.

Figure 2: Enzymatically catalyzed reaction of lactose to galactosyl-oligosaccharides (oligo), galactose (gal), and glucose (glu), adapted from [7]. The substrate fed to the reactor is lactose, comprised of the two monosaccharides galactose and glucose, shown as gal-glu. Product inhibition by galactose formation and enzymatic attack on the desired product (oligosaccharides) are addressed by ultrafiltration, and choice of the proper residence time.

Figure 3: Laboratory scale membrane-assisted reactor system.

Figure 4: Comparison of membrane fluxes using model solutions (all datapoints at steady state after about 30 minutes of run time).

Figure 5: Rising oligosaccharide concentration with rising feed substrate concentration in a membrane-assisted continuous reactor (av. residence time $\mathrm{t}=1 \mathrm{hr}$ ). Open symbol: ceramic membrane MWCO 20,000 g/mol; closed symbols: polymeric membrane MWCO 50,000 g/mol. Temperature and $\mathrm{pH}$ see Table 1.

Figure 6: Oligosaccharide concentration in the permeate at different feed lactose concentrations for different average residence times. Oligosaccharides initially increase but enzymatic hydrolysis stops or reverses this trend. (diamonds: Maxilact L 2000; squares: Gammalactase A 50 P)

Figure 7: HPAEC-PAD chromatogram of products from continuous production of oligosaccharides in a membrane assisted reactor (enzyme Maxilact LX 5000, av. residence time $30 \mathrm{~min}$., $20 \% \mathrm{w} / \mathrm{w}$ lactose feed, $40^{\circ} \mathrm{C}, \mathrm{pH} 7.5$, atech's $\mathrm{UF}_{-} \mathrm{TiO}_{2}$ membrane with nominal molecular weight cut off $20,000 \mathrm{~g} / \mathrm{mol}$, trans membrane pressure $0.5 \mathrm{bar}$ ). $\% \mathrm{w} / \mathrm{w}$ is relative to total mass of saccharides and the total amount of oligosaccharides is calculated on the basis of available standards.

Figure 8: HPAEC-PAD Chromatogram. The concentration of galactosyl-oligosaccharides is calculated on the basis of the shown standards.

a) Our experiments (Feed 20\% w/w lactose, Amano Lactase F, inorganic membrane MWCO $20 \mathrm{kD}, 50^{\circ} \mathrm{C}$ $\mathrm{pH} 4.8$, av. residence time $3 \mathrm{hrs}$ ):

Sample 1: av. residence time $3 \mathrm{hrs}, 29 \mathrm{wt} \%$ galactosyl-oligosaccharides

Sample 2: av. residence time $2 \mathrm{hrs}, 33 \mathrm{wt} \%$ galactosyl-oligosaccharides

b) Oligosaccharide standards (plant derived).

c) Concentrated commercial product. 


\section{Figures}

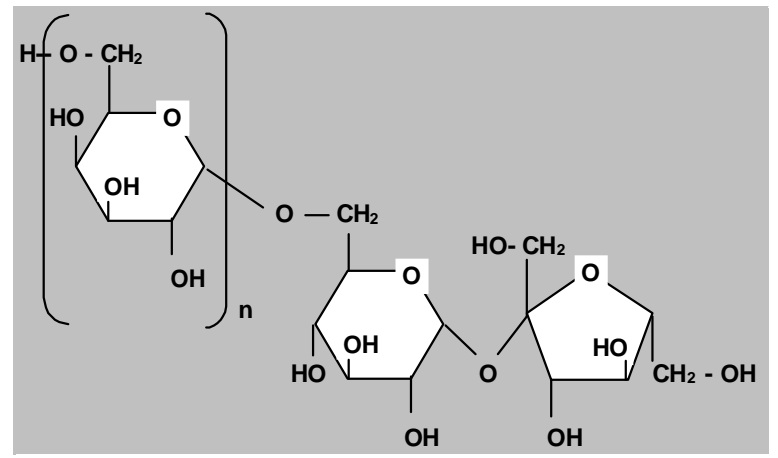

Figure 1: General chemical structure of galactosyl-oligosaccharides. 


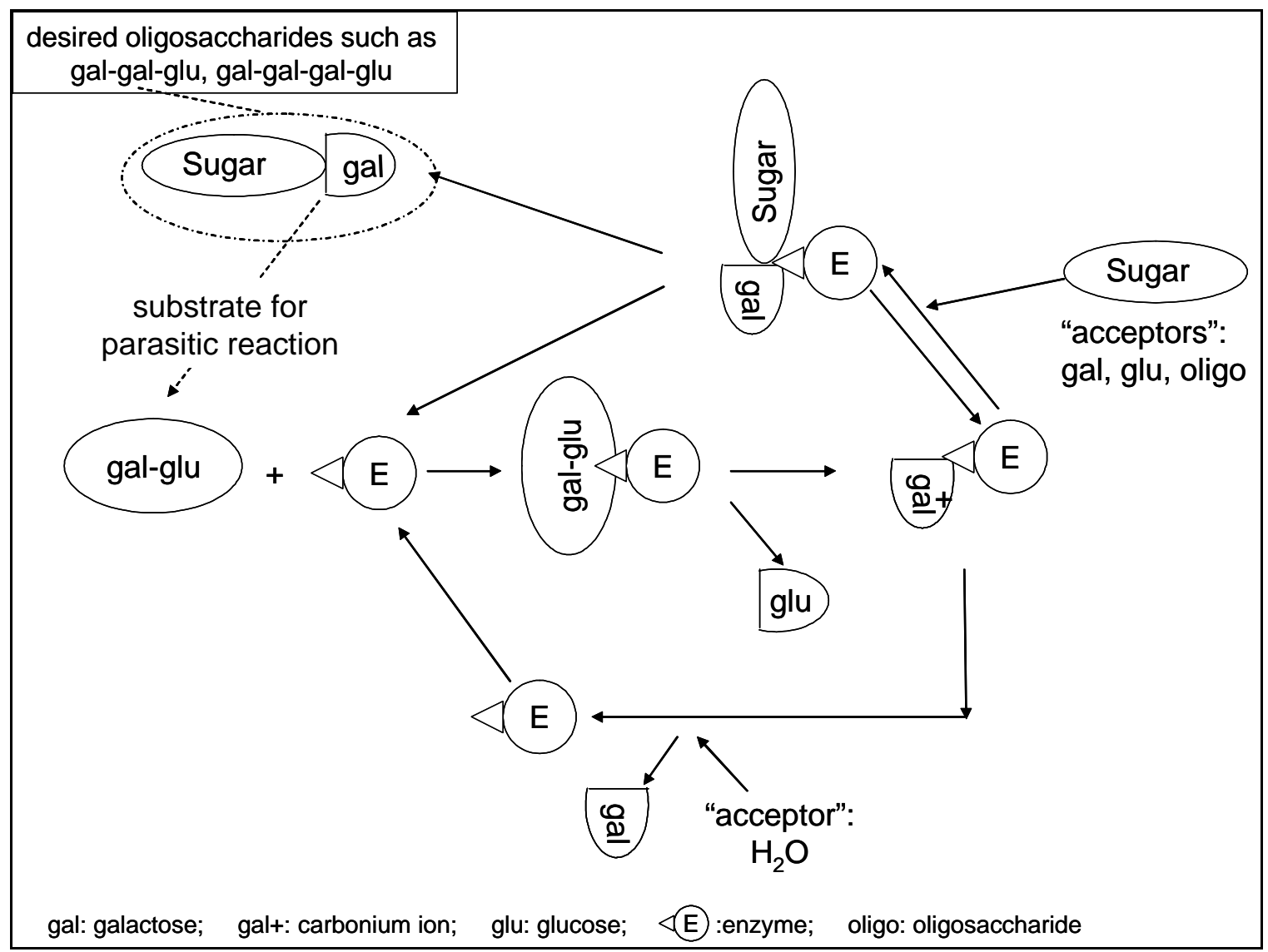

Figure 2: Enzymatically catalyzed reaction of lactose to galactosyl-oligosaccharides (oligo), galactose (gal), and glucose (glu), adapted from [7]. The substrate fed to the reactor is lactose, comprised of the two monosaccharides galactose and glucose, shown as gal-glu. Product inhibition by galactose formation and enzymatic attack on the desired product (oligosaccharides) are addressed by ultrafiltration, and choice of the proper residence time. 


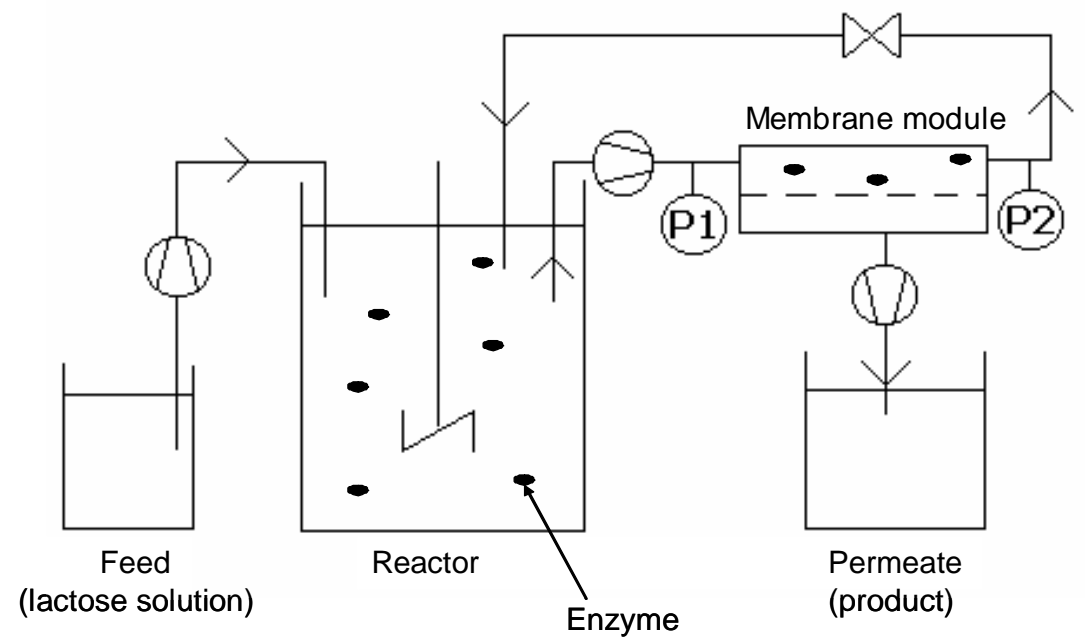

Figure 3: Laboratory scale membrane-assisted reactor system. 


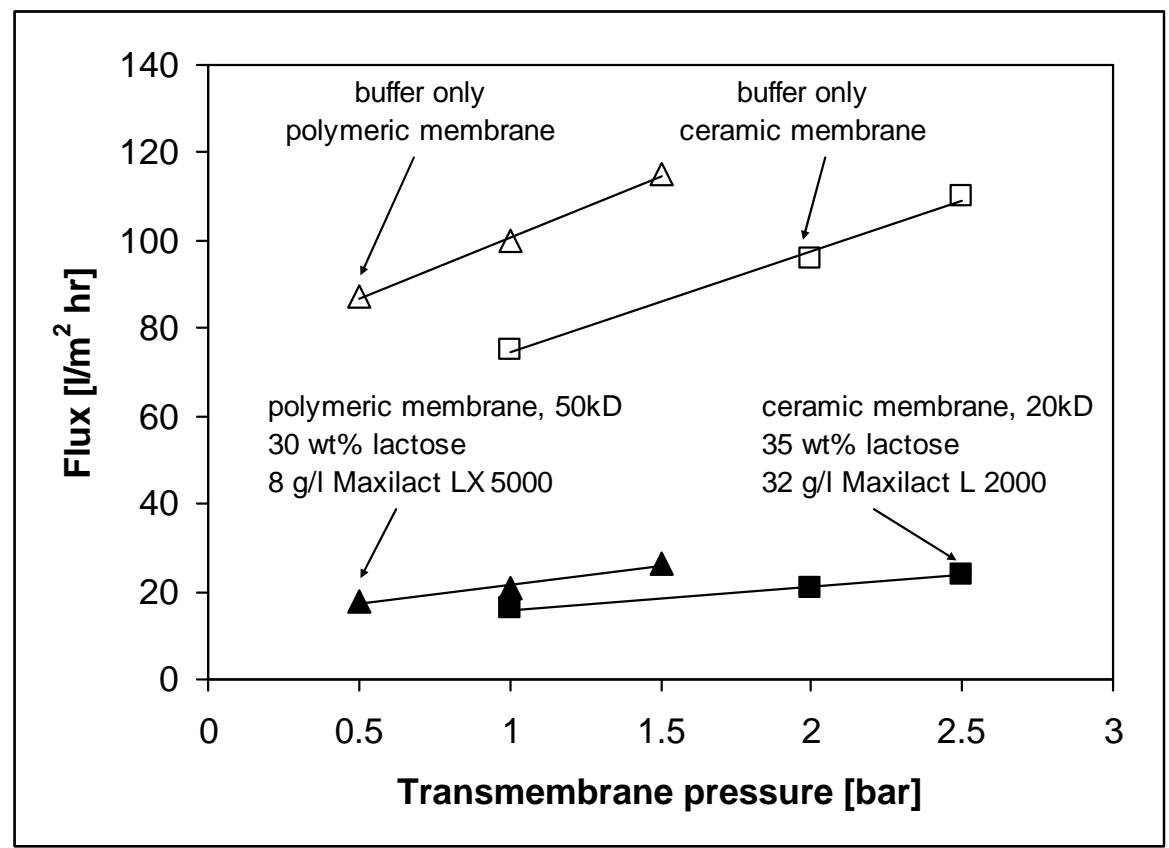

Figure 4: Comparison of membrane fluxes using model solutions (all datapoints at steady state after about 30 minutes of run time). 


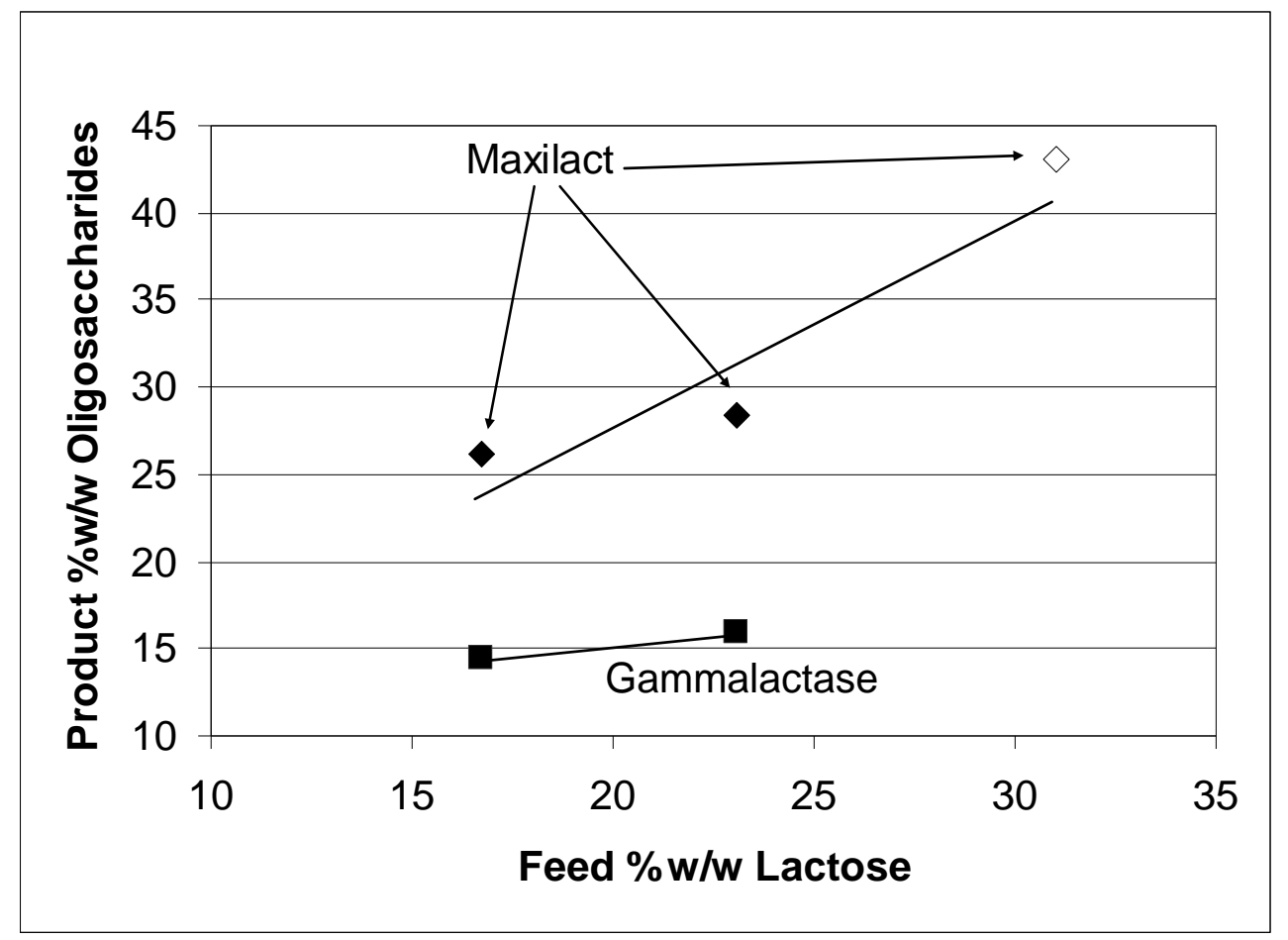

Figure 5: Rising oligosaccharide concentration with rising feed substrate concentration in a membraneassisted continuous reactor (av. residence time $\mathrm{t}=1 \mathrm{hr}$ ). Open symbol: ceramic membrane MWCO 20,000 g/mol; closed symbols: polymeric membrane MWCO 50,000 g/mol. Temperature and pH see Table 1. 


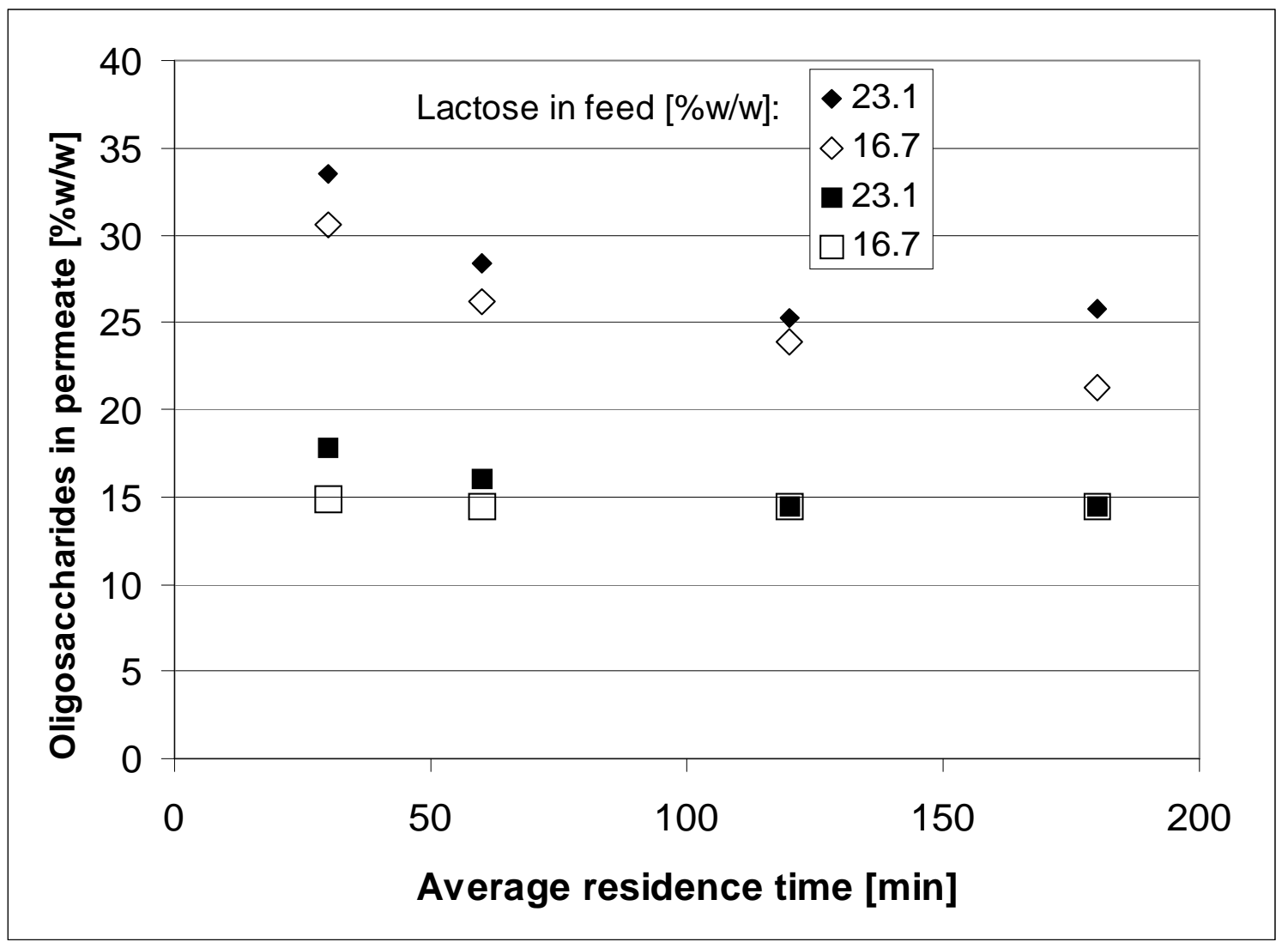

Figure 6: Oligosaccharide concentration in the permeate at different feed lactose concentrations for different average residence times. Oligosaccharides initially increase but enzymatic hydrolysis stops or reverses this trend. (diamonds: Maxilact L 2000; squares: Gammalactase A 50 P) 


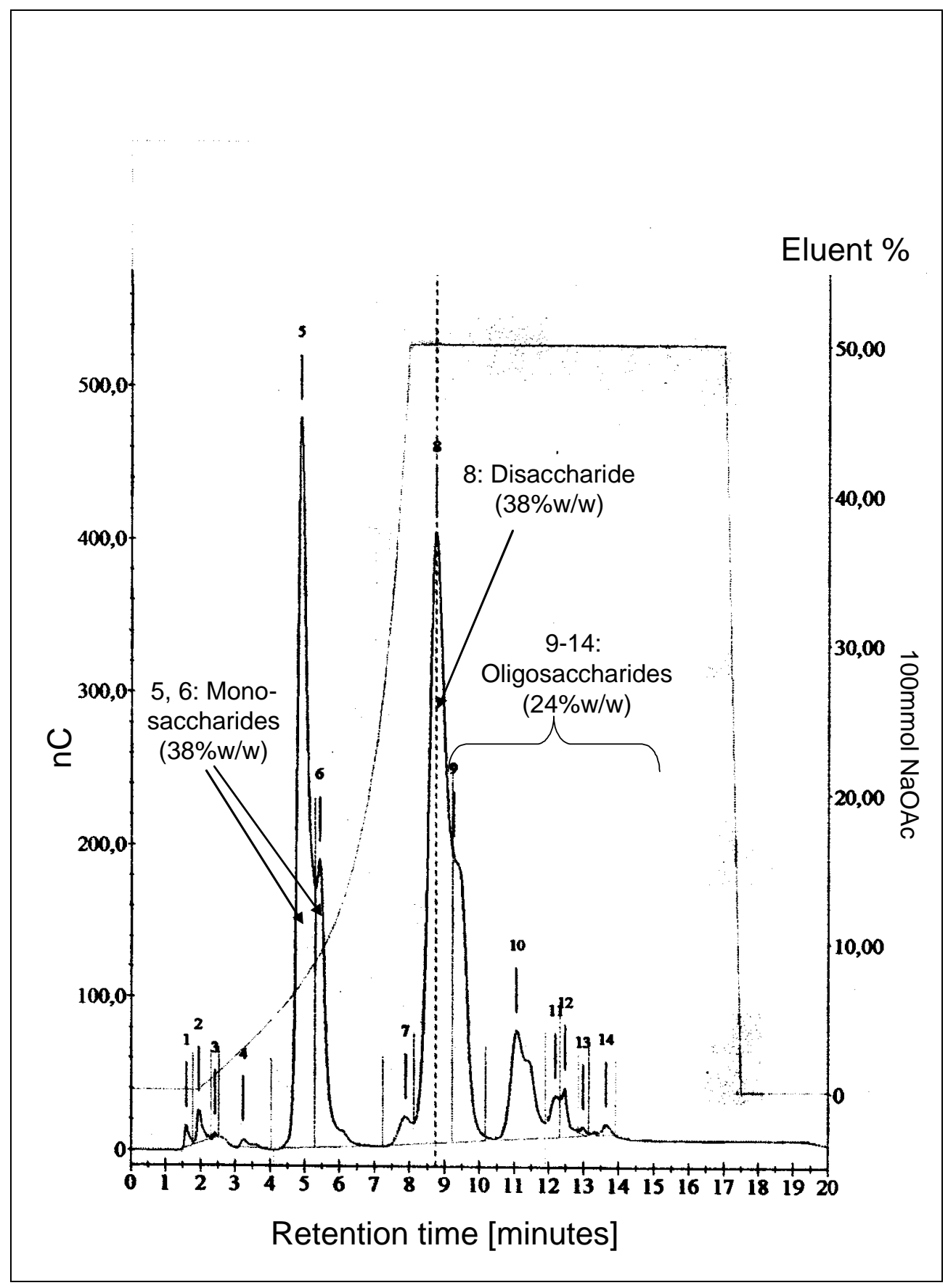

Figure 7: HPAEC-PAD chromatogram of products from continuous production of oligosaccharides in a membrane assisted reactor (enzyme Maxilact LX 5000, av. residence time $30 \mathrm{~min}$., $20 \% \mathrm{w} / \mathrm{w}$ lactose feed,

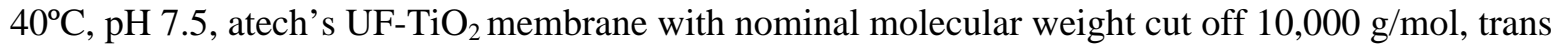
membrane pressure $0.5 \mathrm{bar}$ ). $\% \mathrm{w} / \mathrm{w}$ is relative to total mass of saccharides and the total amount of oligosaccharides is calculated on the basis of available standards. 


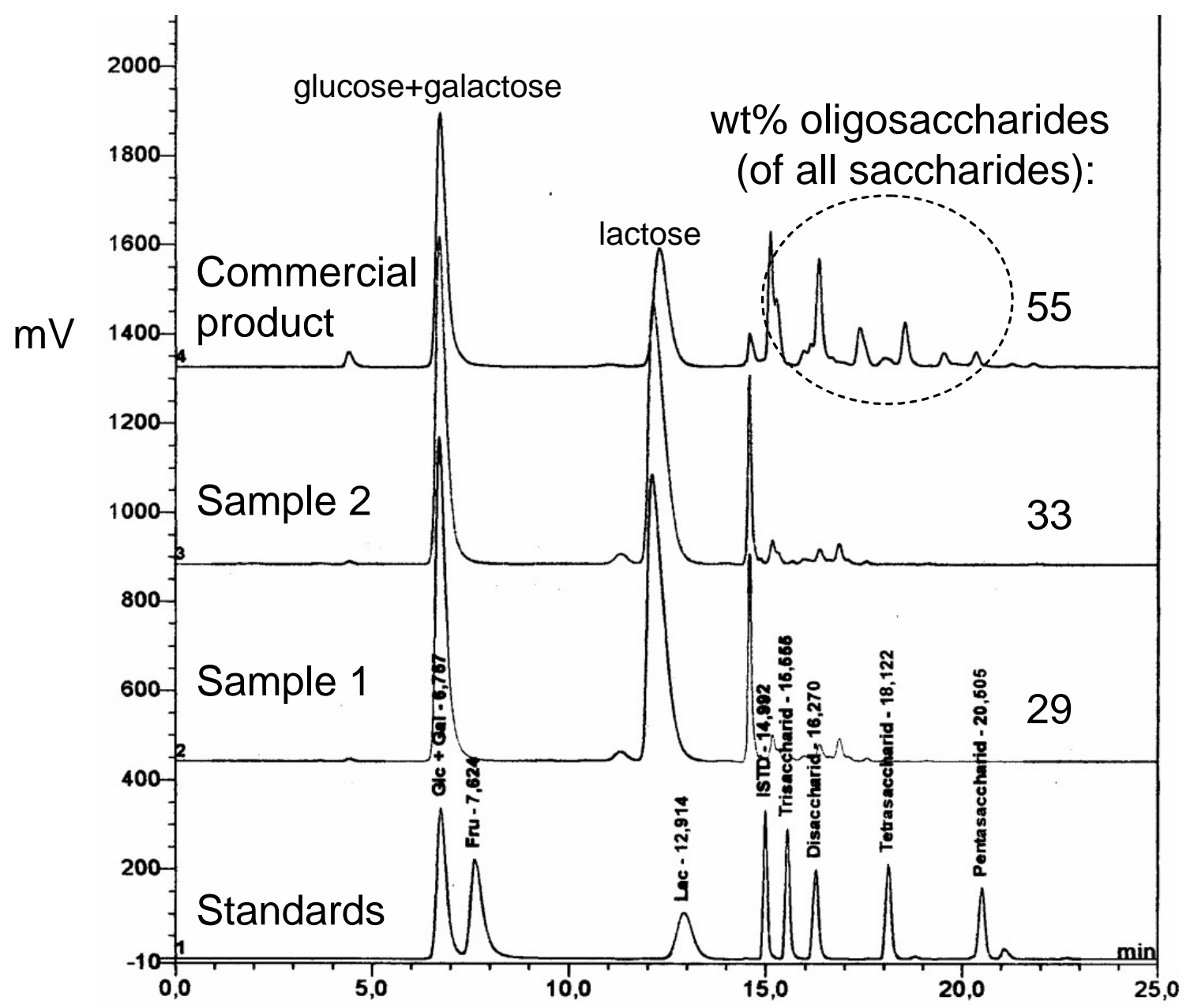

Figure 8: HPAEC-PAD Chromatogram. The concentration of galactosyl-oligosaccharides is calculated on the basis of the shown standards.

a) Our experiments (Feed 20\% w/w lactose, Amano Lactase F, inorganic membrane MWCO $20 \mathrm{kD}, 50^{\circ} \mathrm{C}$ $\mathrm{pH} 4.8$, av. residence time $3 \mathrm{hrs}$ ):

Sample 1: av. residence time $3 \mathrm{hrs}, 29 \mathrm{wt} \%$ galactosyl-oligosaccharides

Sample 2: av. residence time $2 \mathrm{hrs}, 33 \mathrm{wt} \%$ galactosyl-oligosaccharides

b) Oligosaccharide standards (plant derived).

c) Concentrated commercial product. 


\section{Tables}

Table 1: Sources and properties of enzymes.

\begin{tabular}{|c|c|c|c|c|c|c|c|}
\hline \multirow[t]{2}{*}{ Supplier } & \multirow[t]{2}{*}{ Tradename } & \multirow{2}{*}{$\begin{array}{l}\text { Derived from } \\
\text { organism }\end{array}$} & \multicolumn{2}{|c|}{$\begin{array}{c}\text { Optimum } \\
\text { parameters }\end{array}$} & \multicolumn{2}{|c|}{$\begin{array}{c}\text { Our } \\
\text { experiments }\end{array}$} & \multirow[t]{2}{*}{ Activity } \\
\hline & & & $\mathrm{pH}$ & $\begin{array}{l}\text { Temp. } \\
{\left[{ }^{\circ} \mathrm{C}\right]}\end{array}$ & $\mathrm{pH}$ & $\begin{array}{l}\text { Temp. } \\
{\left[{ }^{\circ} \mathrm{C}\right]}\end{array}$ & \\
\hline \multirow{2}{*}{$\begin{array}{l}\text { Gist } \\
\text { Brocades }\end{array}$} & $\begin{array}{l}\text { Maxilact } \\
\text { LX 5000 }\end{array}$ & \multirow{2}{*}{$\begin{array}{l}\text { Kluyveromyces } \\
\text { lactis }\end{array}$} & \multirow{2}{*}{$\begin{array}{l}6.7- \\
7.5\end{array}$} & \multirow[t]{2}{*}{$35-40$} & \multirow{2}{*}{$\begin{array}{l}6.7- \\
7.5\end{array}$} & \multirow[t]{2}{*}{40} & 5,000 \\
\hline & $\begin{array}{l}\text { Maxilact } \\
\text { L } 2000\end{array}$ & & & & & & 2,000 \\
\hline $\begin{array}{l}\text { Amano } \\
\text { Pharmaceutical } \\
\text { Co. }\end{array}$ & Lactase F & \multirow[t]{2}{*}{$\begin{array}{l}\text { Aspergillus } \\
\text { oryzae }\end{array}$} & 5 & 55 & 4.8 & 50 & 10,100 \\
\hline $\begin{array}{l}\text { Gamma } \\
\text { Chemie GmbH }\end{array}$ & $\begin{array}{l}\text { Gamma- } \\
\text { lactase A50P }\end{array}$ & & 4.5 & 50 & 4.7 & 50 & 50,000 \\
\hline
\end{tabular}


Table 2: Membrane materials and properties.

\begin{tabular}{|c|c|c|}
\hline Manufacturer & Amafilter GmbH & $\begin{array}{c}\text { atech innovations } \\
\text { GmbH }\end{array}$ \\
\hline Membrane & UF-PES-050 H & UF-TiO $_{2}$ \\
\hline $\begin{array}{c}\text { Membrane } \\
\text { material }\end{array}$ & $\begin{array}{c}\text { permanently } \\
\text { hydrophilic } \\
\text { polyethersulfone }\end{array}$ & $\begin{array}{c}\text { selective layerTiO } \\
\text { on } \mathrm{ZrO}_{2}\end{array}$ \\
\hline $\begin{array}{c}\text { Nominal mol. } \\
\text { weight cut off } \\
\text { [g/mol] }\end{array}$ & 50,000 & 20,000 \\
\hline $\begin{array}{c}\mathrm{pH} \text { range } \\
\text { Max. } \\
\text { temperature } \\
{\left[{ }^{\circ} \mathrm{C}\right]}\end{array}$ & $0-14$ & $1-14$ \\
\hline
\end{tabular}




\section{References}

[1] M. K. Schmidl and T. P. Labuza, Essentials of Functional Foods, Kluwer Academic/Plenum Publishers, Dordrecht/Netherlands, 2000.

[2] G. Gibson and M. B. Roberfroid, Dietary modulation of the human colonic microbiology: introducing the concept of prebiotics, Journal of Nutrition, 125 (1995) 1401.

[3] S. Salminen, C. Bouley, M. C. Boutron-Roualt, J. Cummings, A. Franck, G. Gibson, E. Isolauri, M.-C. Moreau, M. Roberfroid and I. Rowland, Functional food science and gastrointestinal physiology and function, British Journal of Nutrition, 80(S1) (1998) 147.

[4] H. C. Schoterman, Galacto-oligosaccharides: properties and health aspects, in B. V. McCleary and L. Prosky (Eds.), Advanced Dietary Fibre Technology, Blackwell Science, Oxford, 2001, pp. 494-502.

[5] H. Tomomatsu, Health effects of oligosaccharides, Food Technology, 48 (1994) 61.

[6] Anon., A new oligosaccharide, B(1-4)-galactosyl-lactose, in human milk, Jap. Soc. Bioscience, Biotechnol., Agrochem., Annual Meeting, Hokkaido, Japan, 1995

[7] R. R. Mahoney, Galactosyl-oligosaccharide formation during lactose hydrolysis: a review, Food Chemistry, 63 (1998) 147.

[8] J. E. Prenosil, E. Stuker, and J. R. Bourne, Formation of oligosaccharides during enzymatic lactose hydrolysis and their importance in a whey hydrolysis process: Part II: experimental, Biotechnol. Bioeng., 30 (1987) 1026.

[9] R. D. Appel, A. Bairoch and D. F. Hochstrasser, A new generation of information retrieval tools for biologists: the example of the ExPASy WWW server, Trends Biochem. Sci., 19 (1994) 258. 
[10] M. H. Lopez Leiva and M. Guzman, Formation of oligosaccharides during enzymic hydrolysis of milk whey permeates, Process Biochemistry, 30(8) (1995) 757.

[11] Flaschel, E. and Wandrey, C., Membrane reactors, in K. Buchholz (Ed.), Characterization of immobilized biocatalysts, Dechema Monographien No. 1724-1731, VCH, Weinheim, 1979, p. $337 \mathrm{ff}$.

[12] J. E. Bailey and D. F. Ollis, Biochemical Engineering Fundamentals, McGraw Hill, New York, 1986, 2nd Edition, pp 204ff. 